\section{Science and Politics}

SIR,-I recently received, and also saw in Nature $(237,469 ; 1972)$, a letter from a group at the Open University in Bletchley, England, criticizing me for organizing an Advanced Study Institute on Proteins of the Nervous System under the financial sponsorship of NATO.

The letter states, I believe correctly, that "NATO is primarily a military organization" but "in recent years its activities have ramified in a variety of directions". It then asks whether the deliberations of the meeting are of use for military purposes, if free scientific communication is a permitted consequence, and what the motivations and purposes of the sponsors are.

I was sceptical of sponsorship by an organization with military aims, and was very careful to obtain answers to these same questions, primarily by asking people who had previously organized or participated in such institutes in Neurobiology and Genetics. Only after satisfying myself that no strings were attached did I apply for a grant to NATO. The NATO literature and application forms describe no restraints on who can be invited nor on the content or form of the meeting. The NATO Scientific Affairs Division, which administers the funding of Advanced Study Institutes, strongly urges and almost insists upon independent publication of the proceedings.

Other meetings on the same subject, such as those which have already been held under the sponsorship of the International Society of Neurochemistry and other non-military organizations, are just as likely to lead to military uses of the information discussed. As everyone knows, this is a hazard of basic scientific research in almost any field. Do the signatories to this letter mean to suggest that all meetings relating to the mode of action of the nervous system be forbidden because they might further the development of biological weaponry?

The Open University group also confuses (wittingly or unwittingly) financial support for research and for the purpose of holding meetings. No one can argue intelligently that the purpose of a meeting on proteins of the nervous system, which has fifteen of the world leaders in that field as speakers and which will be openly published, is military. It is absurd to suggest that the organizers, speakers and attendees at the institute are, somehow, being duped by NATO into engaging in a military project.
I do not question the basic motives of the signatories to this letter. I am sure that we agree in our distrust of military organizations and their generally sinister role in our societies. I believe, however, it would be much better to aim at the appropriate targets rather than to shoot wildly at everything in sight, including those projects of NATO which happen to be for a good purpose.

The Open University group sent me a copy of their letter of protest only ten days before our June 1 deadline for receipt of applications-although our meeting had been announced two months before. It was then too late to answer, either publicly or to individuals, the questions they raised. Although we have many more excellent applicants than we can accept from NATO and non-NATO countries, I believe the signatories to the protest letter have been grossly unfair to the organizers of the meeting and to the prospective attendees. Some people who may have wanted to attend may not have applied because they were presented with only one side of the argument.

Finally, and most seriously, such a letter could be bad for the International Society of Neurochemistry (ISN) because it was addressesd to ISN members, and it says that the matter will be brought up at the next ISN meeting. The organization could be irreparably harmed by the creation of political factions. At the very least, one of its major advantages, to provide free communication among neurochemists from all countries, could be destroyed.

I implore the writers of this letter to think seriously before they pursue this course any further, risking harm to this great organization for no good purpose. I also urge the members of ISN to resist any attempts by groups such as this, from any country, to introduce irrelevant polarities into the ISN.

Yours faithfully,

\section{Blake W. Moore}

Department of Psychiatry,

Barnes and Renard Hospitals, 4940 Audubon Avenue, St Louis, Missouri 63110

SIR,-As one of the named participants in the NATO Advanced Study Institute on Proteins of the Nervous System, may I make some comments on the letters of the Brain Research Group (BRG) of the Open University (Nature, 237, 469; 1972) and Dr Giorgi (Nature, 238, 57; 1972).
Dr Giorgi has effectively disposed of the free communication issue as a problem specific to NATO-sponsored conferences. Nevertheless, the point made by the BRG is more generally valid. It is clear, despite the participants from Eastern Europe, that scientists from Cuba or the Democratic Republic of Vietnam would not be welcome at such a meeting. Nor would they be welcome at any meeting held within the United States and most of the American continent. Moreover, the economic and scientific boycott of Cuba, organized by the United States and imposed upon its many allies, is an obvious barrier to free scientific communication. But this can only be opposed by political action to change a political position.

The possible use of scientific meetings to further military research, in particular into CBW, is something which concerns most scientists. Unfortunately, irrespective of the sponsor, the military potential of the work is the same. The decision to be made is not that of participating in certain meetings but whether the research, given its potential, should be carried out. In this, all scientists have an obligation to judge their own work and that of others. Ultimately the problem can only be solved at the political level, and in this context it is worth noting that the movements within the United States against military research have been largely provoked by opponents of the war in Vietnam rather than by scientists objecting only from a general etbical position.

The real problem posed by the BRG is that of whitewashing NATO. This worries me, not because NATO is a military organization, but because it represents the US imperialist system. Participation in NATO conferences can be interpreted as condoning, or at least passively accepting, defoliation, deliberately indiscriminate bombing, anti-personnel weapons of the pineapple bomb type (complete with plastic pellets) and, most recently, deliberate bombing of the system of dams and dykes in the Democratic Republic of Vietnam.

Unlike the Editor of Nature (Nature, 237, 302 and 238, 57; 1972) I do not feel that scientific objectivity implies silence on these matters because "it is a consequence of a declared military policy of a government". Participating in NATO conferences while opposing the system which it represents certainly leaves me open to the charge of opportunism, but I do not think that boycotting a NATO conference is a practical method of fighting US 